\section{Ordforklaringer}

Ultralyd: Alle gravide får tilbud om ultralydundersøkelse rundt uke 18 i svangerskapet. Hensikten med undersøkelsen er å bestemme termin, antall fostre og morkakens leie og å undersøke fosterets anatomi.

PSA: Prostataspesifikt antigen er et protein som produseres av celler i prostatakjertelen. Økte PSA-nivåer i blodet kan være et tidlig tegn på prostatakreft.

\title{
Effekt av ultralyd i uke 18
}

\section{Ultralydundersøkelse i uke 18 gjør at stadig flere fostre med utviklings- avvik oppdages, men det fører ikke til økt antall svangerskapsavbrudd.}

Kristin Offerdal ved Nasjonalt senter for fostermedisin har gjort en prospektiv oppfølgingsundersøkelse av gravide undersøkt i perioden 1987-2004, med nesten 50000 fødsler.

- Det ble registrert 113 tilfeller av klumpfot og 101 tilfeller av leppe-gane-spalte hos fostre/barn i perioden. I begge tilfeller forelå det en forbedret oppdagelsesrate over tid.

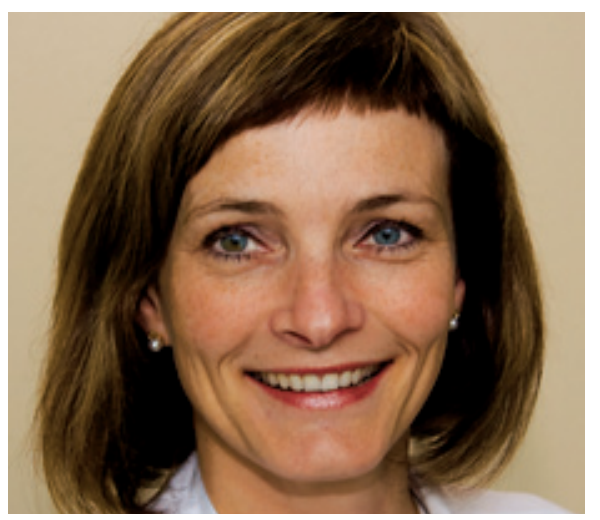

Kristin Offerdal. Foto Morten Dreier, Nasjonalt Senter for Fostermedisin (NSFM)
Det ble registrert 88 tilfeller av Downs syndrom i perioden. Av disse ble $43 \%$ oppdaget hos fosteret $-29 \%$ ved ultralydundersøkelse og bare $14 \%$ ved fostervannsprøve tatt fordi mor var 38 år eller eldre. Det var uendret oppdagelsesrate over tid for Downs syndrom, noe som viser at ultralydundersøkelse i uke 18 ikke er egnet til å påvise syndromet, forteller Offerdal.

- Generelt økte antall funn påvist ved ultralyd i denne 18-årsperioden, samtidig som antall svangerskapsavbrudd på grunn av utviklingsavvik gikk ned. Fagområdet fostermedisin og god oppfølging og veiledning av gravide med funn har vært avgjørende, sier hun.

Offerdal forsvarte avhandlingen Improved ultrasound imaging of the fetus and its consequences for severe and less severe anomalies for ph.d.-graden ved Norges teknisk-naturvitenskapelige universitet 12.12. 2008 .

\section{Anne Forus}

anneforu@online.no

Tidsskriftet

\section{Diagnostikk av tidlig prostatakreft}

\author{
Forhøyet verdi av prostataspesifikt antigen (PSA) er en grunn til \\ å henvise til urolog for mistanke om prostatakreft, men verken \\ denne eller andre markører er spesielt godt egnet til å påvise \\ sykdom tidlig.
}

Prostata vokser med alderen hos de fleste menn. Dette kan gi vannlatingsplager. Prostataveksten er ofte godartet, men kan også være et tidlig tegn på begynnende kreftutvikling. Peder Gjengstø har gått gjennom et klinisk materiale som omfattet 872 pasienter der det var mistanke om tidlig prostatakreft. Han har studert PSA-verdi og verdi av andre markører, vekst av prostata og hvor mange vevsprøver som bør tas for å få en god vurdering.

Gjengstø viser at hovedårsaken til at en pasient henvises til urolog er forhøyet PSA-verdi, ikke vannlatingsplager. Men verken PSA eller andre kjente markører er særlig godt egnet for å påvise tidlig prostatakreft.

Han har også undersøkt godartet vekst av de forskjellige sonene i prostata ved hjelp av ultralydmålinger. Det er kjent at overgangs-/sentralsonen vokser med alderen. Gjengstøs undersøkelser indikerer at også andre deler av prostata («periferisonen») vokser.

Det er ingen konsensus i fagmiljøene om hvor mange vevsprøver som er nødvendig og hvor i prostata disse skal tas. Antallet vevsprøver kan variere fra to til over 20. Gjengstø konkluderer med at seks vevsprøver kan være nok hos eldre pasienter som ikke er kandidater for kurativ behandling.

Han forsvarte avhandlingen Diagnosis of early prostate cancer. A clinical evaluation for ph.d.-graden ved Universitetet i Bergen 27.11. 2008.

\section{Anne Forus}

anneforu@online.no

Tidsskriftet 